\title{
Some Plant Formations from the Arid Regions of Western China.
}

\author{
BY
}

\section{F. KINGDON WARD, B.A., F.R.G.S.}

$\mathrm{T}^{\mathrm{H}}$ $\mathrm{HE}$ arid or semi-desert regions to which the following notes apply comprise several deep trench-like valleys, trending for the most part north and south, which dissect the complicated mountain systems of far western China in the provinces of Kansu, Ssü-chuan, and Yun-nan, or as this country may be comprehensively termed, Chinese Tibet.

As examples to which I shall have occasion to refer we may instance the headwaters of the Min river in Southern Kansu, the T'ung-ho, and the Kin-sha-kiang (or upper Yangtze) in Ssü-chuan, the upper Mekong in North-West Yun-nan, and the upper Salween in South-East Tibet, north of lat. $28^{\circ}$. The arid nature and peculiar vegetation of these gorges in the midst of a region of copious rainfall, certain historical questions which obtrude themselves in connexion with one of the most characteristic components of the open formation met with, and the morphological adaptations of the flora, are interesting points which deserve to be considered in turn ; but at the outset it will be well to explain how these barren gorges have come into existence in the first instance.

The rivers referred to here flow at altitudes varying from about 6,000 to perhaps 10,000 feet above sea-level, while the mountains immediately overshadowing them rise to very much greater altitudes, more especially in the case of the Mekong and Salween rivers.

Apart from the xerophytic nature of the vegetation, the fact that these rivers have been able to cut their way straight down between their investing walls is sufficient evidence for the dryness of the climate in the valleys themselves, but the big alluvial cones debouching into the main valleys speak just as eloquently of a furious rainfall above.

Where the rock is limestone clean-cut gorges are indeed always formed, owing to natural jointing; but even where the rocks are of granite, or of metamorphic origin, these rivers have managed to cut their way straight down, often leaving cliffs of rubble as much as 700 feet high.

Through these funnel-like valleys a daily wind blows up from south to north throughout the summer months with the regularity of a trade wind, springing up shortly before mid-day and dying away after sunset.

[Annals of Botany, Vol. XXVI. No. CIV. October, r9I2.] 
I have remarked this scorching blast in all the valleys alluded to, particularly on the three biggest rivers, the Kin-sha, Mekong, and Salween, strongest of all perhaps on the Mekong, where it is more confined than anywhere else. Throughout the day it increases in ferocity, till about four o'clock in the afternoon it reaches a climax, then gradually calms down towards nightfall ; and though rather of the nature of a sirocco, it is always extremely welcome after the intense heat of the day.

This wind is of course caused by the cold air sweeping down from the surrounding peaks to fill the partial vacuum caused by the great heating of the shut-in valleys during the day, and it greatly intensifies such desert conditions as are already imposed owing to the proximity of the mountains, which act the part of rain-screens. It is indeed a peculiarly desiccating wind, since it has already rid itself of its moisture, and throughout the summer it comes up the valleys like the breath from a hot furnace, till the withered vegetation on the cliffs seems gasping for water. Thus the severity of the conditions increases automatically as one travels northwards, for the intensity of the wind itself increases with the dryness produced by its action.

On the Salween and Mekong rivers an abrupt transition from a rainy region to one of extreme aridity corresponds to a general elevation above the snow-line of the dividing watersheds; the only break in the dreary scene is where a mountain torrent has flung out an alluvial cone which, terraced, and green with cultivation, forms a little oasis in the wilderness.

Travelling up the Mekong valley I have frequently noticed a long ribbon of blue sky faithfully following the valley, while the clouds, though perhaps clear of the mountain peaks, are massed in great puffs of cumulus on either hand, showing plainly enough that columns of hot air are ascending from the valley.

Once in the Mekong valley I watched the clouds in the south, from which snow and rain were actually falling at the time, trying to force their way up the valley into the arid region beyond, where blue sky prevailed; however, they failed signally to cross the dividing line, and it was as though some invisible barrier was forcibly holding them back, the truth being that the hot air rising from the bare rocks prevented any cloud existing as such.

Again, in the Salween valley I have watched the clouds gathering black in the west over the Irrawaddy, watched them sweep slowly over the valley, and reinforced still further, burst again over the Salween-Mekong divide to the east, a few scattered drops hissing on the scorched rocks of the Salween valley alone announcing their passage of that river.

It is abundantly clear then that the arid valleys of Western China owe their inception to just those causes which, on a much larger scale, give rise to continental deserts.

The scarcity of rain, which probably does not exceed five inches in a year, would of itself be a serious hindrance to plant life, and this is 
aggravated by the scorching winds which blow throughout the vegetative season; consequently we here meet with an open formation of stunted shrubs and herbs more or less specialized to combat the hostile conditions.

Characteristic shrubs are Sophora viciiffolia, Bauhinia densiflora, and several other Leguminosae, Clematis Delavayi, Ceratostigma Griffithii, species of Pertya, Wikstroema, and so on, none of them rising more than two or three feet from the ground.

A good deal of bare rock is necessarily exposed-indeed viewed from any distance these gorges often look quite devoid of life, except for the cultivable oases above referred to.

It is worth noting that the usual structure of river valleys is completely reversed in the case of mountain streams entering these arid gorges, and this is particularly true where the rock is of limestone. A river as a rule flows through ravines and gorges near its source, its valley gradually growing broader, till finally the stream is wandering sluggishly across a flat flood-plain. Here, however, a stream having its source high up in the mountains flows in a comparatively broad valley, winding through alpine pastures ; gradually the valley contracts, passing from a typical U-shape in cross section to a pronounced $\mathrm{V}$, the stream plunges down a long stairway, and finally cuts its way abruptly through a deep gorge to join the main river.

In this case the phenomena of reversed valley structure is emphatically a function of the climate apart from the nature and jointing of the rocks. I have drawn attention to it because it accounts satisfactorily for the fact that, while the main valley presents nothing but a dreary waste of rock, scattered amongst which are withered herbs and dwarfed spiny shrubs, the side ravines are often densely choked with vegetation, fresh and green.

This is not due to the fact that the stream itself supplies water to the cliffs and precipices of the gorge, which it certainly does not, but to the circumstance that the sunlight is kept out nearly all day, and consequently the heavy dews in a region of intense radiation are able to supply the requisite amount of water, a point I noticed frequently in the Mekong valley. Future travellers in these regions may however note that this reversed valley structure makes a journey up the Salween or Mekong one of the most appalling nightmares possible.

Though the bigger torrents enter the main valleys through richly vegetated gorges, the smaller and more intermittent ones throw out alluvial cones, and it is under these circumstances that irrigation by means of terracing becomes possible, so that villages occur only where a small stream debouches from the mountains.

Since in South-Eastern Tibet the rain-bearing winds pass over the mountains from the west, the valleys as we go east receive less and less rain, so that the most abrupt transition from a rainy to an arid climate 
occurs, not in the easternmost valley, which is already shut out of a great part of its normal rainfall, but in the most westerly-the valley of the Salween ; nothing indeed could be more striking than the abrupt change from semi-tropical jungles in the southern rainy part of the valley, to semidesert further north, a change rendered all the more striking by a correlated change in the people, from the tribesmen of the jungles to the Tibetans of Tsa-rüng in the north.

Granite occurs frequently in these valleys, and can be recognized from a distance by the clumps of Prickly Pear (Opuntia vulgaris) which grow amongst the 'tors' and boulders of the weathered rock; it apparently grows nowhere else but on granite rocks, and, conversely, wherever granite occurs there also will be found the Prickly Pear. Its interest lies in the fact that Opuntia vulgaris is a native of Mexico or California, and it is worth while inquiring how it found its way into Western China. I have traced it from Kansu through Ssui-chuan to South-East Tibet and Southern Yun-nan, cultivated of course for the sake of its fruit, and such a wide, if discontinuous, distribution at that distance from its original home is curious.

It is not of course the only plant which has wandered far from its home under circumstances hitherto unexplained, or merely conjectured; we need only instance the maize, also said to be a native of Mexico, now cultivated throughout the world. But a cereal of such general utility as maize, in common with rice and other staple grains, was probably distributed over the globe from the very earliest times, whereas such is not likely to be the case with Opuntia, which after all is of no very great importance as a source of food.

Two suggestions present themselves,-the first that it was brought across the Pacific by the Chinese themselves, the second that it was introduced from Europe after it had been brought into the Mediterranean region from across the Atlantic; a third alternative, that it was quite recently introduced by the Jesuit missionaries who came from America to China about the time of the fall of the Spanish Empire, is hardly tenable in view of its present wide distribution in Western China.

There can be little doubt that the Chinese visited California long before Columbus or possibly even the Norsemen discovered America, being carried across the Pacific accidentally by the Kuro Shwio, and voyaging across it when the intrepid Chinese mariners sailed those seas to the Indies, to Japan, perhaps even to Australia. It is equally well established that there was considerable intercommunication between Europe and Asia, particularly between Greece, India, and China, in very ancient times ; and if during this intercourse ideas on art and religion were exchanged, it is highly probable that other things were also, more especially useful plants and the ordinary commodities of trade. 
Let us lastly consider the xerophytic flora in general, noting that one of its most constant features is the 'rosette' habit.

It is well exhibited by Didissandra lamuginosa and other species (10,000-I2,000 feet), Androsace Bulleyana (9,000-II,000 feet), Saxifraga candelabrum (10,000 feet), and even Eremurus chinensis (9,000 feet) with its rosette of stiff spear-like leaves.

It is scarcely necessary to point out that the 'rosette' habit is not peculiar to xerophytes, being common for example on lawns (Taraxacum, Bellis), where it is doubtless brought about by the necessity for exposing as much surface as possible in a limited space, or to mutual pressure of parts.

But when the most successful plant of all found growing under abnormal conditions adopts a peculiar habit, and when moreover this identical habit is found in several other plants growing under similar conditions, we are justified in believing that this habit is in fact an adaptation to withstand those conditions.

Thus the most characteristic plant of all, growing in the semi-desert and arid valleys down as low as 7,000 feet, is Selaginella involvens, which covers the rocks in its thousands.

The 'rosette' habit protects the plant to a considerable extent against undue transpiration, the small, closely packed and overlapping leaves shading one another and forming an admirable protection for the growing point ; moreover, the resulting dwarfed habit implies a minimum exposure of the plant to the desiccating winds, and is doubtless largely due to the brilliance of the direct and reflected light.

But the Selaginella referred to amply protects itself throughout the driest weather by rolling up into a ball like a hedgehog, thus exposing only the under surface of the leaves, which is silvery. Almost exactly the same device is adopted by the Fern Cheilanthes farinosa, each frond of which curls up into a little ball during the dry season, exposing a brightly silvered surface. It will probably be found that this surface, by reflecting the light and heat rays, reduces still further the transpiration from the under sides of the leaves.

Other familiar adaptations are fleshiness, found in several species of Sedum (stem and leaves), besides Opuntia, and the very thick cuticle of Evemurus; we need say nothing about them. But it may be noted that the 'rosette' habit often carries with it a biennial existence, e. g. Androsace Bulleyana and Saxifraga candelabrum, the first year being employed in storing the rosette with reserve food for the final effort of flowering in the second.

Finally, we may point out that there are not a few plants characteristic of the higher arid valleys which present none of the above obvious peculiarities; such are Amphicome arguta and the twining Dregea sinensis. But it is only fair to add that these are not found at the bottom of the deep 
I I Io Ward.-Some Plant Formations from Western China.

trenches where flow the Salween and Mekong rivers in the real semi-desert regions. On the whole perhaps the arid regions of Western China present features more interesting to the geologist than to the botanist, since we find practically the same adaptations to combat the hostile conditions here as are found in waterless regions elsewhere; nevertheless, a comprehensive survey of the flora and its various morphological peculiarities, with a knowledge of all the physical conditions which react on the vegetation, would be most instructive when we come to deal with distribution. For it is just these deep semi-desert valleys which intervene between the Himalayan flora and the flora of Western China. 


\section{$2 \mathrm{BHL}$ Biodiversity Heritage Library}

Kingdon-Ward,

F.

. 1912. "Some plant formations from the arid regions of Western China." Annals of botany 26, 1105-1110.

https://doi.org/10.1093/oxfordjournals.aob.a089433.

View This Item Online: https://www.biodiversitylibrary.org/item/236930

DOI: https://doi.org/10.1093/oxfordjournals.aob.a089433

Permalink: https://www.biodiversitylibrary.org/partpdf/319949

\section{Holding Institution}

Smithsonian Libraries

\section{Sponsored by}

Biodiversity Heritage Library

\section{Copyright \& Reuse}

Copyright Status: Not in copyright. The BHL knows of no copyright restrictions on this item.

This document was created from content at the Biodiversity Heritage Library, the world's largest open access digital library for biodiversity literature and archives. Visit BHL at https://www.biodiversitylibrary.org. 